\title{
Sistem Pendukung Keputusan Untuk Pemilihan Tempat Servis Komputer di Kota Bandar Lampung Menggunakan Metode AHP
}

\author{
Agus Irawan $^{1)}$, Rohaniah ${ }^{2)}$, Heni Sulistiani ${ }^{3)}$, Adhie Thyo Priandika ${ }^{4)}$ \\ ${ }^{1)}$ Sistem Informasi, STMIK Pringsewu \\ 2) Informatika, Universitas Teknokrat Indonesia \\ 3) Sistem Informasi Akuntansi, Universitas Teknokrat Indonesia \\ ${ }^{4)}$ Teknologi Informasi, Universitas Teknokrat Indonesia \\ Jl. Wisma Rini No. 09 Pringsewu, Lampung \\ e-mail:agusirawan814@gmail.com,rhani040@gmail.com ${ }^{2)}$, henisulistiani@teknokrat.ac.id ${ }^{3)}$, \\ thyopriandika919@gmail.com ${ }^{4}$
}

\begin{abstract}
ABSTRAK
Sulitnya memilih tempat servis komputer di Bandar Lampung dikarenakan banyaknya tempat servis yang ada, perbandingan harga dan lamanya proses servis yang ditawarkan pada setiap tempat servis berbeda-beda. Hal ini menyulitkan masyarakat dalam memilih tempat servis yang akan dipilih sebagai alternatif, untuk menyelesaikan masalah tersebuat maka perlu dirancang sebuah sistem pendukung keputusan yang dapat membantu masyarakat untuk memilih tempat servis komputer.

Pada proses pemilihan tempat servis komputer melibatkan berbagai kriteria yang dinilai (bersifat multi kriteria) dengan merapkan metode Analytical Hierarchy Process (AHP). AHP memiliki keunggulan peralatan utama yaitu sebuah hirarki fungsional, dengan hirarki suatu masalah yang kompleks dapat diuraikan kedalam kelompok yang kemudian diatur menjadi suatu hirarki sehingga masalah dapat terstruktur dengan menggunakan kriteria harga, keramahan, fasilitas ruang tunggu, ketepatan waktu pengerjaan, garansi, jarak, kelengkapan jasa, respon / kecepatan tanggap, dan keamanan barang dan dengan 10 alternatif yaitu AsaCom, Basiccom, Laptop Lampung, SuryaCom, Slara Komputer, RR Komputer, Arthabella Komputer, Cahaya Komputer, Indohanif dan Sumber Komputer.

Extreme programming digunakan sebagai metode pengembangan sistem meliputi planning, design, coding dan testing yang akan di uji dengan uji fungsionalitas (Black Box) dan uji kelayakan sistem. Hasil penelitian menunjukan alternatif terbaik adalah Asacom dengan total skor 7.5204 .
\end{abstract}

Kata kunci : AHP, Black Box, Extreme programming, Servis Komputer, Sistem Pendukung Keputusan.

\section{Pendahuluan}

Dalam kehidupan sehari-hari setiap orang pasti akan dihadapkan dengan beberapa pilihan untuk menentukan sebuah pilihan. Namun, dengan adanya beberapa atau banyak kriteria yang menjadi pertimbangan akan menyulitkan para pengambil keputusan dalam penentuan alternatif keputusan.
Sehubungan dengan yang dialami oleh masyarakat kota Bandar Lampung yang memiliki keluhan kerusakan atau error pada perangkat komputernya yang mengharuskan untuk di servis.

Berdasarkan hasil survei yang telah dilakukan oleh penulis sebelumnya, yang melibatkan 15 orang responden yang belum pernah menggunakan jasa servis komputer, didapatkan hasil $80 \%$ responden membutuhkan sebuah sistem yang dapat membantu dalam memilih tempat servis komputer yang sesuai dengan keinginan. Karena selain banyaknya tempat servis yang ada di kota Bandar Lampung, perbandingan harga dan lamanya proses servis yang ditawarkan pada setiap tempat servis berbeda-beda. Hal ini menyulitkan masyarakat dalam memilih tempat servis yang akan dipilih sebagai alternatif.

Permasalahan tersebut dapat diatasi dengan merancang sebuah sistem pendukung keputusan yang nantinya dapat membantu masyarakat untuk memilih tempat servis komputer. Pada proses pemilihan tempat servis komputer melibatkan berbagai kriteria yang dinilai (bersifat multi kriteria). Penelitian ini menggunakan metode AHP karena kelebihannya dibandingkan dengan metode lain terletak pada kemampuannya untuk memecahkan masalah yang multi objektivitas dengan multi kriteria. Tujuan dari penelitian ini adalah untuk memberikan rekomendasi kepada masyarakat dalam pemilihan tempat servis komputer di kota Bandar Lampung.

\section{Pembahasan}

A. Metode Analytical Hierarchy Process (AHP)

Analytical Hierarchy Process (AHP) adalah suatu metode yang dikembangkan oleh Thomas L. Saaty. Peralatan utama AHP adalah sebuah hierarki fungsional dengan input utamanya persepsi manusia. Keberadaan hierarki memungkinkan dipecahnya masalah kompleks atau tidak terstruktur dalam sub bab masalah, lalu menyusunnya menjadi suatu bentuk hierarki.

a. Prinsip Dasar AHP

Pada dasarnya langkah-langkah dalam metode AHP meliputi :

1. Membuat Hierarki 
Sistem yang kompleks dipecah menjadi elemenelemen pendukung dan disusun secara hierarki seperti pada gambar 1 .

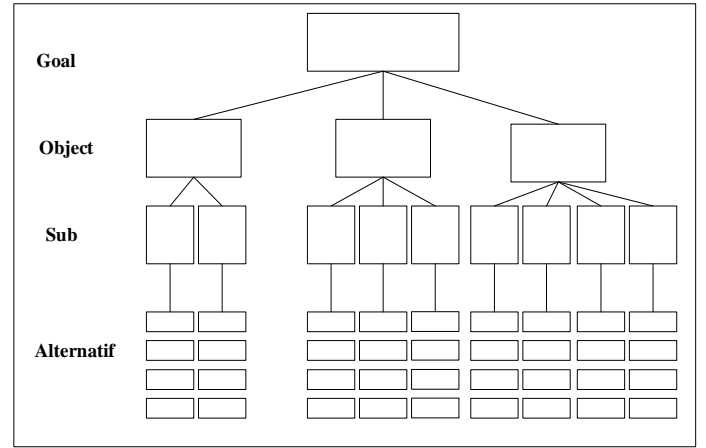

Sumber : (Kusrini, 2007)

Gambar. 1. Struktur Hirarki AHP

\section{Penilaian Kriteria dan Alternatif}

Penilaian kriteria dan alternatif dilakukan dengan perbandingan berpasangan. Untuk berbagai persoalan yang ada, skala 1 sampai 9 adalah skala terbaik dalam mengekspresikan pendapat. Nilai dan definisi pendapat kualitatif dari skala perbandingan dapat dilihat pada tabel 1.

Tabel 1 Skala Penilaian Perbandingan Berpasangan

\begin{tabular}{|c|l|}
\hline $\begin{array}{c}\text { Intensitas } \\
\text { Kepentingan }\end{array}$ & \multicolumn{1}{|c|}{ Keterangan } \\
\hline 1 & Kedua elemen sama pentingnya \\
\hline 3 & $\begin{array}{l}\text { Elemen yang satu sedikit lebih } \\
\text { penting daripada yang lainnya }\end{array}$ \\
\hline 5 & $\begin{array}{l}\text { Elemen yang satu lebih penting } \\
\text { daripada yang lainnya }\end{array}$ \\
\hline 7 & $\begin{array}{l}\text { Satu elemen jelas lebih mutlak } \\
\text { penting daripada elemen lainnya }\end{array}$ \\
\hline 9 & $\begin{array}{l}\text { Satu elemen mutlak penting daripada } \\
\text { elemen lainnya }\end{array}$ \\
\hline Kabalikan & $\begin{array}{l}\text { Nilai-nilai antara dua nilai } \\
\text { pertimbangan-pertimbangan yang } \\
\text { berdekatan }\end{array}$ \\
\hline $\begin{array}{l}\text { Jika aktivitas i mendapat satu angka } \\
\text { dibandingkan dengan aktivitas j, } \\
\text { maka j memiliki nilai kebalikannya } \\
\text { dibandingkan dengan i }\end{array}$ \\
\hline
\end{tabular}

\section{Penentuan Prioritas (Synthesis of Priority)}

Untuk setiap kriteria dan alternatif, perlu dilakukan perbandingan berpasangan (Pairewise Comparisons). Nilai perbandingan relatif dari seluruh alternatif dan kriteria dapat disesuaikan dengan penilaian yang telah ditentukan untuk menghasilkan bobot dan prioritas. Bobot dan prioritas dihitung melalui penyelesaian persamaan matematik.

\section{Konsistensi Logis (Logical Consistency)}

Konsistensi memiliki dua makna. Pertama, objekobjek yang serupa bisa dikelompokkan sesuai dengan keseragaman dan relevansi. Kedua, menyangkut tingkat hubungan antar objek yang didasarkan pada kriteria tertentu.

\section{b. Prosedur Penyelesaian AHP}

1. Mendefinisikan masalah dan menentukan solusi yang di inginkan, lalu menyusun hierarki dari permasalahan yang dihadapi. Penyusunan hierarki adalah dengan menetapkan tujuan yang merupakan sasaran sistem secara keseluruhan pada level teratas.

2. Menentukan prioritas elemen

a. Langkah pertama dalam menentukan prioritas elemen adalah membuat perbandingan pasangan, yaitu membandingkan elemen secara berpasangan sesuai kriteria yang diberikan.

b. Matriks perbandingan berpasangan diisi menggunakan bilangan untuk merepresentasikan kepentingan relatif dari suatu elemen terhadap elemen lainnya.

3. Sintesis

Pertimbangan-pertimbangan terhadap perbandingan berpasangan di sintesis untuk memperoleh keseluruhan perioritas. Hal-hal yang dilakukan dalam langkah ini adalah :

a. Menjumlahkan nilai-nilai dari setiap kolom pada matriks.

b. Membagi setiap nilai dari kolom dengan total kolom yang bersangkutan untuk memperoleh normalisasi matriks.

c. Menjumlahkan nilai-nilai dari setiap baris dan membaginya dengan jumlah elemen untuk mendapatkan nilai rata-rata.

4. Mengukur Konsistensi

Dalam pembuatan keputusan, penting untuk mengetahui seberapa baik konsistensi yang ada karena kita tidak menginginkan keputusan berdasarkan pertimbangan dengan konsistensi yang rendah. Hal-hal yang dilakukan dalam hal ini adalah :

a. Kalikan setiap nilai pada kolom pertama dengan prioritas relatif elemen pertama, nilai pada kolom kedua dengan prioritas relatif elemen kedua, dan seterusnya.

b. Jumlahkan setiap baris.

c. Hasil dari penjumlahan baris dibagi dengan elemen prioritas relatif yang bersangkutan.

d. Jumlahkan hasil bagi di atas dengan banyaknya elemen yang ada, hasilnya disebut $\lambda$ maks

5. Hitung Consistency Index (CI) dengan rumus : $\mathrm{CI}=(\lambda$ maks $-\mathrm{n}) /(\mathrm{n}-1)$

Dimana $\mathrm{n}=$ banyaknya elemen 
6. Hitung Rasio Konsistensi / Consistency Ratio

(CR) dengan rumus:

\section{$\mathrm{CR}=\mathrm{CI} / \mathrm{RC}$}

Dimana $\mathrm{CR}=$ Consistency Ratio

$\mathrm{CI}=$ Consistency Index

IR = Indeks Random Consistency

Memeriksa konsistensi hierarki. Jika nilainya lebih besar dari $10 \%$, maka penilaian data judgment harus diperbaiki. Namun jika rasio konsistensi (CI/IR) kurang atau sama dengan 0.1 , maka hasil perhitungan bisa dinyatakan benar.

\section{B. UML (Unified Model Language)}

Menurut [4] "UML (Unified Modeling Language) adalah salah satu standar bahasa yang banyak digunakan di dunia industri untuk medefinisikan requirement, membuat analisis dan desain, serta menggambarkan arsitektur dalam pemograman berorientasi objek".

\section{Extreme Programming}

Extreme Programming (XP) adalah sebuah pendekatan atau model pengembangan perangkat lunak yang mencoba menyederhanakan berbagai tahapan dalam proses pengembangan tersebut sehingga menjadi lebih adaptif dan fleksibel.

\section{WEB}

Web Pada dasarnya website adalah kepanjangan dari Word Wide Web (WWW). Informasi WWW ini disimpan pada web server untuk dapat diakses dari jaringan browser terlebih dahulu, seperti Internet Explorer atau Mozilla Firefox. Menurut [6] , "Jenis website dapat dikategorikan menjadi dua yaitu web statis dan web dinamis"

\section{E. $P H P$}

PHP merupakan script yang berintergrasi dengan HTML dan berada pada server (server-side HTML embedded scripting). PHP adalah script yang digunakan untuk membuat halaman web menjadi lebih dinamis dan interaktif.

\section{F. Black Box}

Pengujian metode Black Box merupakan pengujian terhadap fungsionalitas input/output dari suatu perangkat lunak, metode ini digunakan untuk mengetahui apakah perangkat lunak berfungsi dengan benar.

\section{Metode Penelitian}

A. Perhitungan metode AHP

Pada sistem pendukung keputusan pemilihan tempat servis komputer di kota Bandar Lampung menggunakan 10 tempat yang digunakan sebagai alternatif dapat dilihat pada tabel 2 dan menggunakan 9 kriteria yang dapat dilihat pada tabel 3 .
Tabel 2 Alternatif

\begin{tabular}{|c|c|c|c|}
\hline No & Alternatif & $\begin{array}{c}\text { Nama } \\
\text { Toko }\end{array}$ & Alamat Toko \\
\hline 1 & A1 & AsaCom & $\begin{array}{l}\text { Jl. Teuku Umar, No.16, } \\
\text { Kedaton, Bandar } \\
\text { Lampung }\end{array}$ \\
\hline 2 & $\mathrm{~A} 2$ & BasicCom & $\begin{array}{l}\text { Jl. Teuku Umar, } \\
\text { No.37E, Kedaton, } \\
\text { Bandar Lampung }\end{array}$ \\
\hline 3 & A3 & $\begin{array}{l}\text { Laptop } \\
\text { Lampung }\end{array}$ & $\begin{array}{l}\text { Jl. Zainal Abidin Pagar } \\
\text { Alam, Labuhan Ratu, } \\
\text { Kedaton, Bandar } \\
\text { Lampung }\end{array}$ \\
\hline 4 & A4 & SuryaCom & $\begin{array}{l}\text { Jl. Sumantri } \\
\text { Bojonegoro, Raja Basa, } \\
\text { Bandar Lampung }\end{array}$ \\
\hline 5 & A5 & $\begin{array}{l}\text { Slara } \\
\text { Komputer }\end{array}$ & $\begin{array}{l}\text { Jl. Teuku Umar No.8 } \\
\text { Surabaya, Kedaton, } \\
\text { Bandar Lampung }\end{array}$ \\
\hline 6 & A6 & $\begin{array}{l}\text { RR } \\
\text { Komputer }\end{array}$ & $\begin{array}{l}\text { Jalan Malabar 2, Blok } \\
\text { K - No. 19, Perumnas } \\
\text { Way Halim, Bandar } \\
\text { Lampung }\end{array}$ \\
\hline 7 & A7 & $\begin{array}{l}\text { Arthabella } \\
\text { Komputer }\end{array}$ & $\begin{array}{l}\text { Jl. Jend A Yani, No } \\
.8 / 12 \text {, Gunungsari, Tj. } \\
\text { Karang Pusat }\end{array}$ \\
\hline 8 & A8 & $\begin{array}{l}\text { Cahaya } \\
\text { Komputer }\end{array}$ & $\begin{array}{l}\text { Jl. Soemantri } \\
\text { Brojonegoro, Jalur II } \\
\text { Unila, Kp. Baru, } \\
\text { Bandar Lampung }\end{array}$ \\
\hline 9 & A9 & Indohanif & $\begin{array}{l}\text { Jl. Teuku Umar } \\
\text { No.405D, Sidodadi, } \\
\text { Kedaton, Bandar } \\
\text { Lampung }\end{array}$ \\
\hline 10 & A10 & $\begin{array}{l}\text { Sumber } \\
\text { Komputer }\end{array}$ & $\begin{array}{l}\text { J1. Jend. Sudirman } \\
\text { No.68 G, Rw. Laut, } \\
\text { Engal, Bandar } \\
\text { Lampung }\end{array}$ \\
\hline
\end{tabular}

Tabel 3 Kriteria

\begin{tabular}{ccl}
\hline \hline No & Kriteria & \multicolumn{1}{c}{ Keterangan } \\
\hline 1 & C1 & Ketepatan Waktu Pengerjaan \\
2 & C2 & Harga \\
3 & C3 & Keamanan Barang \\
4 & C4 & Respon \\
5 & C5 & Garansi \\
6 & C6 & Keramahan \\
7 & C7 & Kelengkapan Jasa \\
8 & C8 & Jarak \\
9 & C9 & Fasilitas Ruang Tunggu \\
\hline \hline
\end{tabular}


Dengan penyelesaian AHP sebagai berikut.

1. Membuat hierarki alternatif keputusan

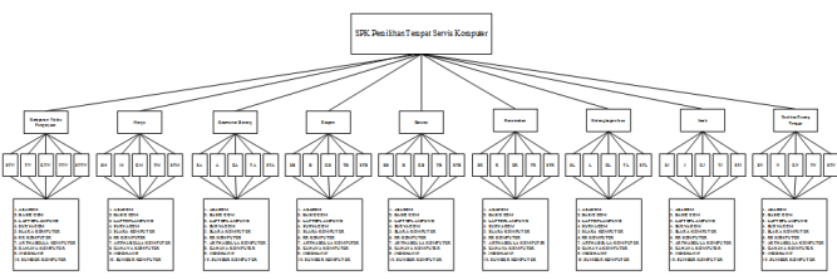

Gambar. 2. Hierarki alternatif keputusan

2. Membuat matrik perbandingan berpasangan

Contoh kasus pada kolom berwarna merah
pada tabel $3.4:$
$0.33=1 /$ elemen
Elemen $=[\mathrm{x}, \mathrm{y}]$
Elemen $=[2,1]$
$1 / 3=0,333$

Setelah melakukan perbandingan berpasangan, maka langkah selanjutnya melakukan normalisasi. Konsistensi Logis (Logical Consistency)

a. Menentukan nilai Eigen Maksimum ( $\chi$ maks)

$\chi$ maks $=($ Jumlah $/ \mathrm{n})$

$\chi$ maks $=11.139 / 9$

jadi $\chi$ maks 1.238

b. Menentukan Index Konsistensi (CI)

$\mathrm{CI}=((\chi$ maks $-\mathrm{n}) / \mathrm{n}))$

$\mathrm{CI}=((1.238-9) / 9))$

Jadi, CI -0.86248634

c. Menghitung Rasio konsistensi (RI)

CR diperoleh dari pembagian antara CI dan RI, dimana nilai RI adalah ketentuan berdasarkan jumlah kriteria yang digunakan.

Untuk $\mathrm{n}=9$, maka nilai $\mathrm{RI}=1.45$

$\mathrm{CR}=\mathrm{CI} / \mathrm{RI}$

$\mathrm{CR}=\frac{-0.86248634}{1.45}$

$\mathrm{CR}=-0.59481817$

Hasil perhitungan CR untuk pemilihan tempat servis komputer $<=0,1$ maka rasio konsistensi dari perhitungan tersebut diterima.

3. Menentukan Prioritas sub kriteria dari kriteria ketepatan waktu pengerjaan. Setelah kriteria utama ditemukan nilai konsistensinya maka langkah berikutnya adalah menentukan prioritas sub kriteria dari masing-masing kriteria.

4. Menentukan hasil perhitungan

Dari hasil perhitungan kriteria utama dan sub prioritas. Jadi, alternatif terbaik adalah Asacom dengan total skor 7.5204 dari total 10 alternatif yang tersedia.

\section{B. Pemodelan Sistem}

Use case diagram mendiskripsikan sebuah interaksi antara satu atau lebih aktor dengan sistem informasi yang akan dibuat. Gambaran use case yang digunakan pada penelitian ini dapat dilihat pada gambar 3 .

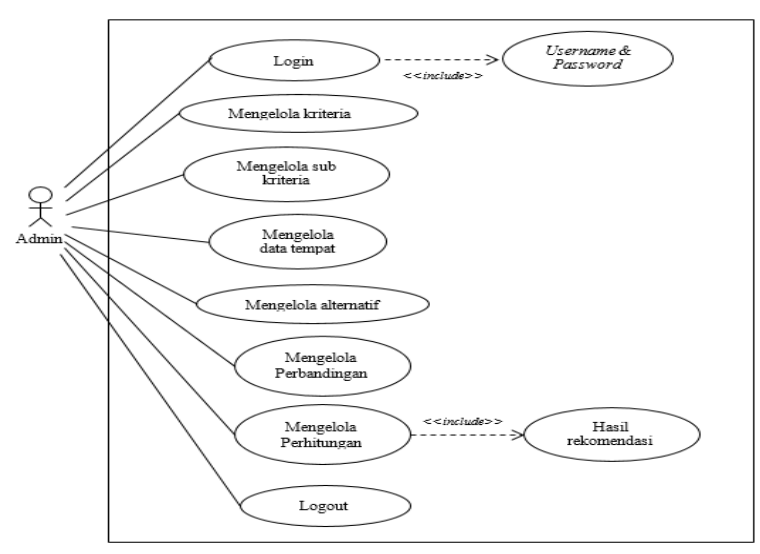

Gambar. 3. Use Case Diagram

\section{Hasil Penelitian dan Pembahasan}

\section{A. Implementasi Web}

Dalam tahap implementasi sistem memberikan gambaran desain yang telah di rancang pada tahap pengembangan sistem pendukung keputusan pemilihan tempat servis komputer.

1. Halaman Utama

Halaman beranda adalah interface yang tampil setelah login berhasil. Beranda berisi tampilan admin lengkap dengan profil admin yang login, keriteria, alternatif, perhitungan, beserta hasil hitung.

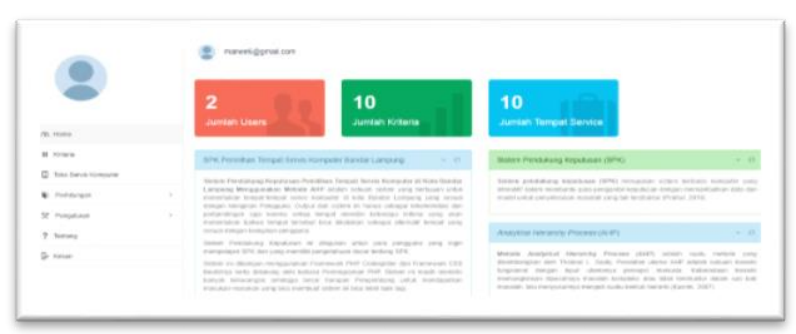

Gambar. 4. Halaman Utama

2. Halaman Kriteria

Halaman data kriteria untuk menginputkan data kriteria dan menyimpan seta menampilkan data kriteria yang telah diinputkan. 


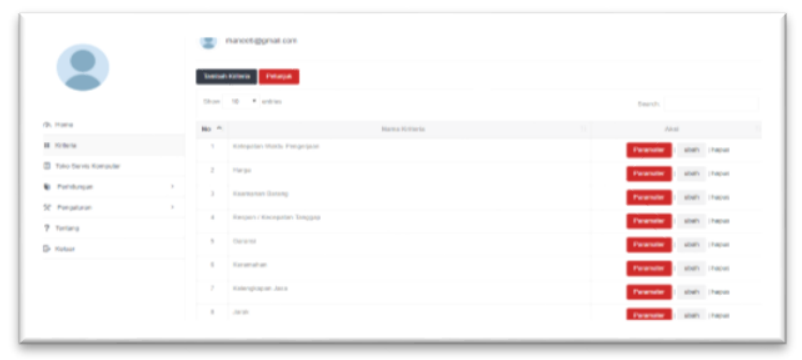

Gambar. 5. Halaman Kriteria

3. Halaman Subkriteria

Halaman sub kriteria untuk menginputkan data sub kriteria dan menyimpan serta menampilkan data kriteria yang telah diinputkan.

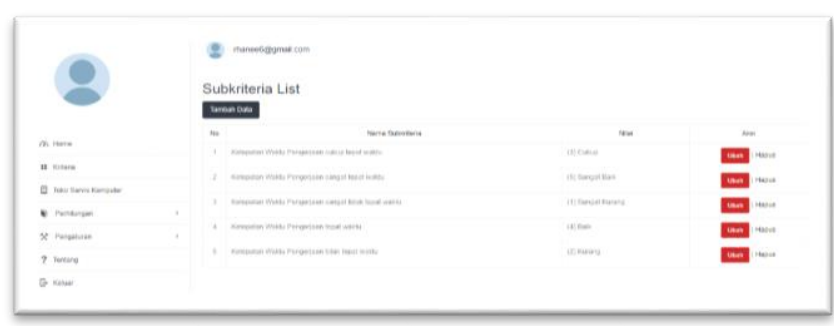

Gambar. 6. Halaman Sub Kriteria

4. Halaman Perhitungan > Alternatif

Halaman Perhitungan $>$ Alternatif untuk menampilkan, menambah, dan menghapus data alternatif yang akan digunakan dalam perhitungan.

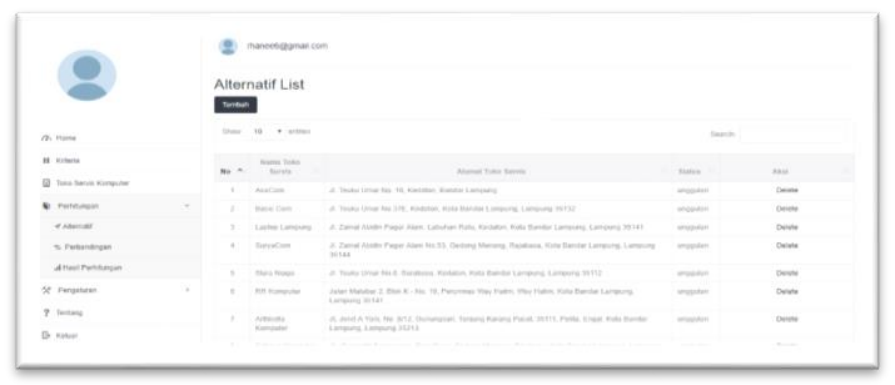

Gambar. 7. Halaman Perhitungan > Alternatif

5. Halaman Perhitungan $>$ Perbandingan

Halaman Perhitungan > Perbandingan menampilkan data nilai preferensi yang dapat dipilih untuk membuat matrik perbandingan berpasangan.

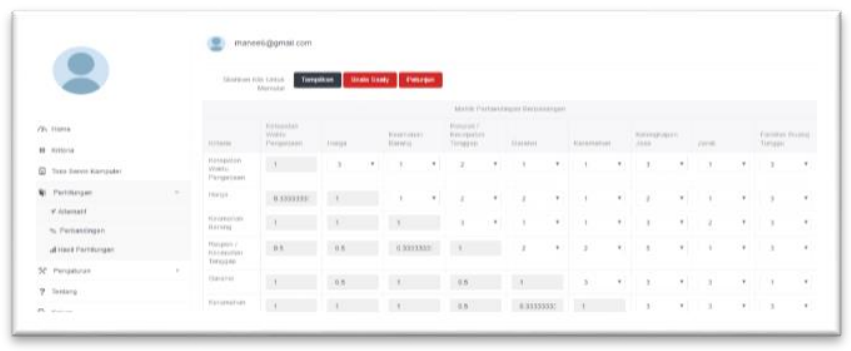

Gambar. 8. Perhitungan > Perbandingan
6. Halaman Perhitungan $>$ Hasil

Halaman Perhitungan > Hasil menampilkan hasil akhir dari perhitungan.

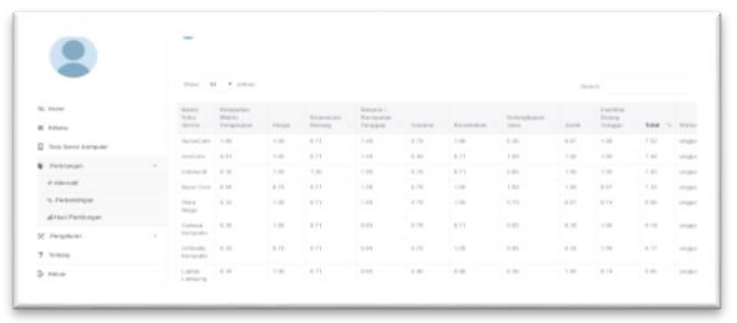

Gambar. 9. Perhitungan > Hasil

B. Hasil Pengujian

Berikut hasil uji kelayakan sistem secara keseluruhan Sistem Pendukung Keputusan.

Tabel 4 Hasil uji kelayakan

\begin{tabular}{|l|c|c|c|c|}
\hline Aspek & $\begin{array}{l}\text { SKOR } \\
\text { AKTU } \\
\text { AL }\end{array}$ & $\begin{array}{l}\text { SKO } \\
\text { R } \\
\text { IDE } \\
\text { AL }\end{array}$ & $\begin{array}{l}\text { \%SKO } \\
\text { R } \\
\text { AKTU } \\
\text { AL }\end{array}$ & $\begin{array}{l}\text { KRITE } \\
\text { RIA }\end{array}$ \\
\hline $\begin{array}{l}\text { Fungsi } \\
\text { onal } \\
\text { Admin }\end{array}$ & 60 & 70 & 86 & $\begin{array}{l}\text { LAYA } \\
\text { K }\end{array}$ \\
\hline Total & 60 & 70 & 86 & $\begin{array}{c}\text { LAYA } \\
\text { K }\end{array}$ \\
\hline
\end{tabular}

\section{Kesimpulan dan Saran}

A. Kesimpulan

Berdasarkan hasil penelitian dan pembahasan sistem pendukung keputusan untuk pemilihan tempat servis komputer di kota Bandar Lampung menggunakan metode AHP, maka dapat disimpulkan

1. Telah dibangun sebuah sistem berbasis web yang dapat membantu pengguna memilih tempat servis komputer berdasarkan keinginan, kebutuhan sehingga pengguna akan mendapatkan alternatif yang terbaik.

2. Proses perhitungan hasil tes menggunakan metode AHP dengan 9 kriteria yaitu ketepatan waktu pengerjaan, harga, keamanan barang, respon / kecepatan tanggap, garansi, keramahan, jarak, kelengkapan jasa, dan fasilitas ruang tunggu yang telah dilakukan dengan menggunakan pengujian Black Box memperoleh presentase $86 \%$ dan mendapatkan klasifikasi Layak.

\section{B. Saran}

Berdasarkan kesimpulan dari hasil penelitian yang telah diuraikan, maka saran yang dapat diberikan untuk penelitian selanjutnya terhadap Sistem Pendukung Keputusan Untuk Pemilihan Tempat 
Servis Komputer Di Kota Bandar Lampung Menggunakan Metode AHP yaitu:

1. Untuk pengembangan aplikasi dapat dibuat dalam bentuk aplikasi mobile berbasis android.

2. Untuk penelitian selanjutnya dapat digunakan metode lain dalam penyelesaian keputusan

\section{Daftar Pustaka}

Pratiwi, H., “Analytical Hierarchy Process, ”dalam Buku Ajar Sistem Pendukung Keputusan, 1 ed, Yogyakarta, 2016, Deepublish, hal. 27-81.
Lupiyaodi, R., Manajemen Pemasaran Jasa. Jakarta: Salemba Empat, 2013.

Kusrini, Analytical Hierarchy Process, dalam Konsep dan Aplikasi Sistem Pendukung Keputusan, 1 ed, Yogyakarta: Andi Offset, 2007.

Rosa, A. S. \& Salahuddin, M., Rekayasa Perangkat Lunak Terstruktur dan Berorientasi Objek. Bandung: Informatika Bandung, 2016.

Ferdiana, R., Rekayasa Perangkat Lunak: Lunak Yang Dinamis Dengan Global Ectreme Programming, Yogyakarta: Andi, 2012.

Kustiyahningsih, Yeni \& Devie, R. A., Pemrograman Basis Data Berbasis Web Menggunakan PHP \& MySQL, Yogyakarta: Graha Ilmu, 2011. 